ЕФЕКТИВНІСТЬ МЕХАНІЗМІВ ДЕРЖАВНОЇ ПОЛІТИКИ СОЦІАЛЬНО-ЕКОНОМІЧНИХ ГАРАНТІЙ У ЗБРОЙНИХ СИЛАХ УКРАЇНИ ДЛЯ ВІЙСЬКОВОСЛУЖБОВЦІВ НА СУЧАСНОМУ ЕТАПІ

\title{
EFFECTIVENESS OF PUBLIC POLICY MECHANISMS OF SOCIO-ECONOMIC WARRANTIES IN THE ARMED FORCES OF THE UKRAINE FOR MILITARY SERVANTS ON MODERN STAGE
}

Проаналізовано процеси надання соціально-економічних гарантій військовослужбовцям під час їх постійного перебування в середовищі української армії. Сутність соціально-економічних гарантій військовослужбовців переважно розкривається в контексті практик соціальної відповідальності та гуманізму державної влади. Задоволення даних базових груп потреб дозволяє оцінювати ефрективність не лише соціальних гарантій, а й усієї системи соціалізації військовослужбовців. Через систему соціально-економічних гарантій військовослужбовиям гарантується не лише комплекс заходів соціальної підтримки та компенсацій, а й реалізуються соціальні проекти, що забезпечують достойні умови проходження військової служби. Соціальний захист військовослужбовиів характеризується системою соціально-економічних гарантій, що забезпечують відповідний соціально-економічний комплекс пільг. Соціальний потенціал військовослужбовців характеризує створений комплекс конкретизованих навичок і військових здібностей, які необхідні й повинні бути використані у процесі здійснення службової діяльності. Досліджено особливості актуального соціального стану військовослужбовців під час проходження служби у Збройних Силах України. Соціально-економічні гарантії військовослужбовців $є$ не лише конкретизованої формою прояву державних мінімальних соціальних стандартів життєдіяльності військовослужбовця, а й визначають основні напрями реалізації їхнього соціального захисту. Дані гарантії є основними елементами системи соціального захисту військовослужбовців у наш час. Соціально-економічні гарантії мають розглядатися як механізми забезпечення, військовослужбовиів, як окремої просресійної групи, що уособлюють якісну характеристику загального переліку соціальних пілье. В умовах трансорормацій громадянського суспільства створюються передумови оновлення всієі системи соціального захисту населення, забезпечення соціально необхідних умов відновлення військового потенціалу. Формування диспропорцій в системі стимулювання праці військовослужбовців веде до зростання соціальної напруженості у військових організачіях, гальмування процесів саморозвитку військовослужбовців. Державна система соціальних пілье у нових умовах повинна забезпечувати не лише збереження, а й стійке зростання соціально-економічні умов споживчого розвитку військовослужбовців. З'ясовано необхідність удосконалення механізмів державного політики економічного забезпечення військової служби на сучасному етапі. Соціальний захист не обмежується лише системою пільг, він доповнюється системою гарантій, спрямованих на подолання ризиків діяльності, здійснення мотивації якісного виконання службових фуункцій. Соціально-економічні параметри відображають не лише рівень мінімального матеріального забезпечення військовослужбовців, а й відповідність характеру і діапазону виконуваних дій військовослужбовців. Оцінка соціально-економічних гарантій визначається через аналіз прочесів досягнення результатів гарантування захисту, підвищення ефективності державної соціальної політики. Вона повинна оцінюватися в результаті аналізу системи гарантій рівня державного забезпечення умов життєдіяльності військовослужбовців. При цьому мінімально необхідний рівень задоволення біологічних потреб може оцінюватися через аналіз рівня забезпечення гарантій за переліком мінімальних соціальних стандартів.

Ключові слова: соціально-економічні гарантії, сучасний етап, механізми державної політики, військовослужбовці, ефективність, Збройні Сили України.

The processes of providing social and economic guarantees to servicemen during their permanent stay in the Ukrainian army are analyzed. An analysis of the provision of housing for certain privileged categories of citizens, in particular, combatants and persons equated to them, participants in the war, servicemen, suggests that these categories of citizens have significant problems with the realization of their right to housing. Improvement of mechanisms for the formation and implementation of state policy in the area of realization of housing rights of Ukrainian citizens should provide for the establishment of stable financial flows in the form of investment in construction with the aim of increasing coordination between the pace of formation of the mortgage and real estate market. The peculiarities of the actual social status of servicemen during their service in the Armed Forces of Ukraine are investigated. In the process of socialization of a serviceman, the social formation and development of the personality occurs, the formation of an almost new complex multi-level hierarchical system of various values that regulate its behaviour and activity, depending on the features of the social adaptation to it. Socialization of the servicemen is understood as a complex social process of mastering by a person of new system of knowledge, and, as well, improving and adaptation to the changed social environment of already known systems of knowledge, standards and values, in the conditions of social influence that allow him to function as a full member of civil society. Despite the growth of social tension and dissatisfaction in the military environment, the decline in the prestige of military service and the authority of the profession of defender of the Fatherland, thousands of young officers want to devote their lives to serving their people and the state. If this state does not care about their proper and comprehensive social protection, then it will not be any more sense to speak not only about the combat capability of the troops and the defense capability of the state, but also about the existence of the Ukrainian army. 
The necessity to improve the mechanisms of state policy of economic provision of military service at the present stage has been clarified. The variety of mechanisms for using the funds provided by the state budget under the relevant budget program, the main spending units and responsible implementers of the budget program, budget managers of the lower level, and objects for the purchase of which may be sent to the budget funds causes the inconvenience of purchasing housing for the specified category citizens, and difficulties in purchasing housing for different budget programs in one residential building. It is necessary to rethink the social values and to determine the quality of the activities of such a social and professional group, as the army officers; they are not only subjects of professional activity, but also active participants of all state changes. At the same time, their professional socialization is a key factor that directly influences the development of benchmarks and standards of behaviour and the activity of officers. It is also important that in the conditions of an acute economic crisis and limited resources, the cost of military activities has become one of the priorities. In the process of socialization of a serviceman, the social formation and development of the personality occurs, the formation of an almost new complex multi-level hierarchical system of various values that regulate its behaviour and activity, depending on the features of the social adaptation to it. Socialization of the servicemen is understood as a complex social process of mastering by a person of new system of knowledge, and, as well, improving and adaptation to the changed social environment of already known systems of knowledge, standards and values, in the conditions of social influence that allow him to function as a full member of civil society.

Key words: socio-economic guarantees, current stage, mechanisms of state policy, servicemen, efficiency, Ukrainian Armed Forces.
Постановка проблеми в загальному вигляді. Соціально-економічні гарантії та механізми соціальної політики держави потрібно розглядати як найважливіші елементи системи соціального захисту військовослужбовців. Соціально-економічні гарантії військовослужбовців $€$ не лише конкретизованої формою прояву державних мінімальних соціальних стандартів життєдіяльності військовослужбовця, а й визначають основні напрями реалізації їхнього соціального захисту. Дані гарантії $€$ основними елементами системи соціального захисту військовослужбовців у наш час. Соціально-економічні гарантії мають розглядатися як механізми забезпечення, військовослужбовців, як окремої професійної групи, що уособлюють якісну характеристику загального переліку соціальних пільг.

Сутність соціально-економічних гарантій військовослужбовців переважно розкривається в контексті практик соціальної відповідальності та гуманізму державної влади. Задоволення даних базових груп потреб дозволяє оцінювати ефективність не лише соціальних гарантій, а й усієї системи соціалізації військовослужбовців. Соціально-економічні гарантії спрямовані не лише на підтримку населення та усунення негативних наслідків нерівності у суспільстві, а й на підвищення ефективності соціальної інтеграції різних груп соціуму. Важливою $€$ сутність соціального захисту як соціального інституту, що розкриває процеси розробки та поняття соціально значущих норм на основі уточнених мінімально необхідних індивідуальних потреб військовослужбовців.

Аналіз останніх досліджень і публікацій. У межах аналізованих підходів можна помітити, що дослідники розглядають державну соціальну політику як широкий комплекс організаційної дії, що спрямована на соціальний захист населення. Соціально-економічні гарантії військовослужбовців повинні визначатися як діяльність держави, що спрямована на реалізацію соціального захисту, що здійснюється через досягнення відповідного рівня гарантій. Соціально-економічні гарантії військовослужбовців мають характеризуватися показниками соціальної захищеності, як результату забезпечення соціально-економічних інтересів, прав і свобод військовослужбовців.

Дослідники приходять до висновку, що система соціального захисту в умовах соціально-економічних трансформацій залучена в систему ринку і є його невід'ємним елементом [4, с. 45]. Державна соціальна політика традиційно розглядається, як система державних, галузевих, організаційних та цілеспрямованих дій з регулювання соціально-економічних відносин, що складаються між різними соціальними групами соціуму. Реалізується ця політика через механізми державного регулювання соціально-економічних відносин між соціальними групами, а також через активізацію процесів соціалізації. Державна соціальна політика забезпечує соціальний захист суспільно прийнятного і бажаного рівня матеріального, а також соціального благополуччя військовослужбовців.

Мета статті - обґрунтувати необхідність підвищення ефективності державної політики соціально-економічних гарантій військовослужбовцям у Збройних Силах України на сучасному етапі.

Виклад основного матеріалу. Соціальноекономічні гарантії військовослужбовця це, перш за все, комплекс прав, які надаються військовослужбовцям відповідними державними структурами [2, с. 54]. Військовослужбовцям переважно надається соціальний захист не у 
формі соціальних пільг, а у формі державних соціально-економічних гарантій. Останні спрямовуються не лише на протидію соціальним ризикам, але і на створення оптимальних умов відновлення і саморозвитку, мотивацію службової діяльності. Цей перелік гарантій військовослужбовцям необхідно розглядати як інструменти, засоби, методи, а також механізми реалізації соціальних функцій держави.

Соціальний захист військовослужбовців уособлюється у вигляді набору матеріальних, а також юридичних засобів, спрямованих на забезпечення реалізації конституційних прав військовослужбовця. Соціально-економічні гарантії військовослужбовців є сукупністю норм, що забезпечують реалізацію законодавчо закріплених соціальних прав, можливості користування встановленими законом свободами. Ці гарантії необхідно розглядати як матеріальні, соціальні, духовні та правові умови, що забезпечують не лише можливість відтворювати людський потенціал військовослужбовця, а й використовувати встановлені законодавством права і свободи. Соціальні-економічні гарантії визначаються можливостями громадянського суспільства відповідно до досягнутого економічного рівня, наявності матеріальних ресурсів для їх підтримки та реалізації.

Соціально-економічні гарантії надаються державою, відомчими структурами та військовими організаціями, вони спрямовані на дотримання соціальних прав військовослужбовця. В рамках даного підходу соціальні гарантії військовослужбовців повинні реалізуватися механізмами державного регулювання. Соціальний захист військовослужбовців здійснюється в рамках прийнятої системи соціальних гарантій, визначених, як сукупність матеріальних, організаційних, економічних механізмів, що забезпечують їх права. Це державні зобов'язання перед військовослужбовцями, взяті суспільством на себе і спрямовані на забезпечення необхідних умов життєдіяльності та відтворення їх духовного і фізичного потенціалу.

Державна соціальна політика в даному контексті $€$ процесом соціально-економічного регулювання, що здійснюється в результаті реалізації управління, спрямованого на забезпечення гарантій для військовослужбовців. Соціально-економічні гарантії військовослужбовців необхідно розглядати як державний механізм утримання їх прав у суспільстві в цілому і у військових організаціях зокрема [6, с. 21]. Система соціального захисту військовослужбовців полягає у здійсненні державної діяльності, спрямованої на реалізацію комплексу завдань, пов'язаних із підтримкою та реалізацію соціально-економічних гарантій. Ці гарантії спрямовані на забезпечення прав військовослужбовців та на створення умов відновлення професійної діяльності, підтримки їх власної гідності та статусу в суспільстві.

Через систему соціально-економічних гарантій військовослужбовцям гарантується не лише комплекс заходів соціальної підтримки та компенсацій, а й реалізуються соціальні проекти, що забезпечують достойні умови проходження військової служби. Соціальний захист військовослужбовців характеризується системою соціально-економічних гарантій, що забезпечують відповідний соціально-економічний комплекс пільг. Отож, соціальний потенціал військовослужбовців характеризує створений комплекс сукупних знань, умінь, здоров'я, культури і моральності, а також конкретизованих навичок і військових здібностей, які необхідні й повинні бути використані у процесі здійснення службової діяльності.

В умовах трансформацій громадянського суспільства створюються передумови оновлення всієї системи соціального захисту населення, забезпечення соціально необхідних умов відновлення військового потенціалу. Формування диспропорцій в системі стимулювання праці військовослужбовців веде до зростання соціальної напруженості у військових організаціях, гальмування процесів саморозвитку військовослужбовців. Державна система соціальних пільг у нових умовах повинна забезпечувати не лише збереження, а й стійке зростання соціально-економічні умов споживчого розвитку військовослужбовців. В умовах соціально-економічної реформи суспільства актуальними $є$ удосконалення гарантій, що забезпечують стабілізацію доходу, матеріального і нематеріального забезпечення військовослужбовців.

Сучасна система соціально-економічних гарантій військовослужбовців регулює процеси соціальної підтримки даної групи населення за напрямками, доходу, охорони здоров'я та освіти. Ефективний механізм даних гарантій визначає можливість доступу військовослужбовців до матеріальних, інформаційних, освітніх ресурсів [1, с. 24]. На сучасному етапі соціально-економічних реформ не лише конкретизуються параметри, система соціальних пільг, а й визначаються основні їх напрямки, формуються самостійні вектори соціального захисту військовослужбовців. Підтримка стабільного соціально необхідного рівня військовослужбовців визначає умови їх якості життя, добробуту, а значить і споживчих потреб військовослужбовця. 
Державні соціально-економічні гарантії поширюються на всі важливі для військовослужбовця блага і послуги, як мінімального рівня фінансової підтримки, житла, освіти, послуг системи охорони здоров'я. Соціальноекономічні гарантії $€$ основною умовою стабільності не лише окремих військовослужбовців, але й усієї системи військової організації в державі. Дані гарантії військовослужбовців мають бути спрямовані на підтримку відповідного матеріального рівня військовослужбовця, що у свою чергу створює об'єктивні умови для соціальної стабільності.

Військово-армійські організації обумовлені зв'язками, залежностями, відносинами, і як цілісні комплекси динамічно функціонуючих факторів, спрямовані на досягнення економічних та соціальних цілей, реалізації соціального захисту військовослужбовців. Впровадження практик соціально-економічних гарантій на рівні окремої військової організації не лише забезпечує стабільний розвиток військовослужбовців, а й $є$ результатом сформованої соціальної потреби військової організацій мати кваліфікований кадровий потенціал. У період реформ державна система соціально-економічних гарантій характеризується як суспільно-владна модель, реформи відрізняються різким зниженням привабливості служби в збройних силах, статус військовослужбовця невисокий, соціальні гарантії обмежені та постійно піддаються трансформаціям не завжди на користь військовослужбовців.

Здійснюється не лише перехід до динамічного розвитку, зміцнення економіки, а й активно оновлюються вектори розвитку громадянського суспільства [5, с. 67]. Сучасний рівень розвитку інституту соціально-економічних гарантій військовослужбовців є результатом функціонування військової організації і життєдіяльності військовослужбовців з відображенням реформ громадянського суспільства в цілому. Сучасні умови реформування української армії передбачають необхідність формування моделі новітніх соціально-економічних гарантій військовослужбовців, це $є$ результатом реформи всієї системи соціального захисту.

У соціальній економіці розвинених країн військово-професійний вибір і реалізація військової служби дає змогу досягти істотного зростання рівня життя, отримати комплексні соціальні гарантії більш високого рівня в порівнянні з іншими категоріями населення. Це дає можливість державі забезпечити умови, що дозволяють військовослужбовцям не лише сумлінно виконувати обов'язки військової служби, а й отримувати високий рівень доходу, послуги охорони здоров'я та освіти. Формування соціально-економічних гарантій для військовослужбовців є процесом, що реалізується в системі соціально-економічного розвитку громадянського суспільства.

Система соціально-економічних гарантій для військовослужбовців розвивається і оновлюється в результаті врахування інтересів суспільства, яке залежне і взаємопов'язане з динамікою господарського розвитку держави. В результаті ефективної державної соціальної політики доповнюються і збагачуються соціальні-економічні гарантії військовослужбовців, формується належний рівень соціальних стандартів їх життєдіяльності. Це призводить до розвитку соціально-економічних гарантій для військовослужбовців та підвищення рівня інтеграції організаційних систем, військовослужбовців і громадського суспільства в цілому. Усі типи соціально-економічних гарантій спрямовані на забезпечення прийнятих і діючих державних стандартів, тобто на забезпечення необхідного матеріального стандарту життя військовослужбовців.

Соціальні гарантії забезпечують умови розвитку потреб і здібностей, умови професійного зростання, оновлення всієї системи життєдіяльності військовослужбовця. Система цих гарантій формує додаткові компоненти, що визначають захисні функції держави і кожної окремої воєнізованої організації. Гарантії задоволення освітніх потреб військовослужбовців сприяють підтримці умов освітнього відтворення їх потенціалу. Підтримка освітніх практик на певному рівні сприяє оптимізації процесів, спрямованих на формування освітнього потенціалу військовослужбовця.

Соціально-економічні гарантії в галузі охорони здоров'я сприяють підтримці нормальних умов фізичного відтворення військовослужбовця, сприяють стабілізації відновлення його функціональних здібностей. Реалізація соціально-економічних гарантій для військовослужбовця повинна приводити до розвитку демократичних прав і свобод їх діяльності. У результаті розвитку їх особисті службові здібності в цілому інтегруються, стають більш стабільно відтвореними і однорідними. Інтегрується вся система гарантій військовослужбовців, створюються умови відновлення і саморозвитку їхнього потенціалу. Процес забезпечення розвитку потенціалу військовослужбовців розглядається як одна з цілей функціонування системи соціально-економічних гарантій військовослужбовців.

Соціально-економічні гарантії $€$ механізмом забезпечення соціальних прав, стабілізації умов взаємодії населення і військовос- 
лужбовців. Система соціально-економічних гарантій військовослужбовців є комплексом, що відображає діяльність соціальних інститутів, спрямовану на реалізацію захищеності та стандарти, що забезпечують гарантії та права, дозволяють їм підтримувати нормальні умови життєдіяльності, відтворювати власний людський потенціал. Соціальний захист здійснюється через розроблення і законодавче закріплення соціально-економічних гарантій, які одночасно $€$ передумовою і базою забезпечення процесів відновлення і розвитку потенціалу військовослужбовців, створення рівних умов для членів окремих військових організацій та суспільства загалом.

Державні соціально-економічні гарантії при стратегічному розгляді не лише спрямовані на забезпечення стандартів життєдіяльності, а й визначають зростання ефективності діяльності військовослужбовців. Вонизабезпечують стійкість процесів накопичення суспільних цінностей, стабільність перспективного соціально-економічного розвитку військових структур. Соціально-економічні гарантії конкретизуються в нормах соціальної підтримки та компенсацій, вони розширюють використання діяльних професійних можливостей військовослужбовців у стратегічній перспективі. Дані гарантії спрямовані на забезпечення стабільності функціонування військовослужбовця в поточному періоді та на забезпечення можливості підвищення фізичних та інтелектуальних даних.

Це уособлює процес конструювання послідовних прогресивних змін, що забезпечують розвиток фізичних і духовних сил військовослужбовців, вони мають отримувати додаткові матеріальні виплати, які постійно збільшуються щодо інфляційних змін. Соціальний захист військовослужбовців покликаний реалізувати компенсаційну функцію за базовими показниками повністю, а по інших напрямках частково. Система соціального захисту покликана здійснювати регулятивний вплив на професійну діяльність, вдосконалювати соціально-економічні відносини військовослужбовців [3, с. 19]. Ця функція, реалізується через конституційні механізми права на освіту, відпочинок, медичне обслуговування, право на соціальні послуги та соціальне забезпечення. У контексті реалізації соціальних-економічних гарантій також створюються необхідні умови для соціалізаційної діяльності військовослужбовців, здійснюється часткове стимулювання ініціативи, активної позиції.

Соціально-економічні гарантії покликані не лише забезпечити нормальні умови життєдіяльності військовослужбовців, а й забез- печити відновлення фізичного та освітнього потенціалу, визначити напрямки і можливість розвитку професійних даних військовослужбовців як суб'єктів військової організації. У сучасних умовах необхідно розробляти комплексну систему оцінки соціально-економічних гарантій військовослужбовців спрямованих на соціальний захист, оцінку фінансових, організаційних, соціальних та стимулюючих заходів, що проводяться військовими організаціями з метою забезпечення і створення військовослужбовцям необхідних умов для якісного виконання своїх обов'язків.

Ця група гарантій повинна забезпечити соціально значимий процес фізичного відновлення потенціалу військовослужбовців, а оцінка доступу до освітніх послуг здійснюється в результаті аналізу практик нарощення знань, професійних умінь, навичок, а також здібностей застосовування людського потенціалу в діяльних практиках. Ці процеси проявляються у формалізації освітніх послуг у вигляді отримання військовослужбовцем ознак зростання освітнього потенціалу. Оцінка гарантій доступу до освітніх послуг не може обмежуватися лише аналізом практик, вона повинна будуватися ще й на дослідженні тенденцій розвитку освітнього простору, оцінки фактів вдосконалення цінностей.

Соціальні гарантії збереження і розвитку здоров'я $є$ стрижневою основою відновлення фізичних даних в цілому і фізичного потенціалу військовослужбовців зокрема, держава повинна гарантувати можливість військовослужбовцю відтворювати своє здоров'я. Уявлення про здорову особистість уособлюється як певний соціальний стандарт, на який орієнтується діюча система соціальних гарантій. Ця система на отримання послуг охорони здоров'я постійно трансформується і оновлюється разом з розвитком суспільства та військової організації. Соціально-економічні гарантіїгарантують можливість військовослужбовцю відтворювати своє здоров'я, будуються на принципі цінностей в загальноприйнятому соціально-економічному просторі.

Ефективність системи соціально-економічних гарантій на отримання послуг соціального обслуговування військовослужбовців прийнято оцінювати за показниками підтримки загальної системи життєдіяльності та розвитку соціального потенціалу військовослужбовця. Ці гарантії покликані забезпечити можливість відтворення здоров'я як системної характеристики якісного стану фізичного потенціалу військовослужбовця. Даний комплекс соціальних гарантій покликаний удосконалювати процес розвитку соціального капіталу, створювати 
сприятливе середовище життєдіяльності військовослужбовця в цілому.

Висновки. Військова організація конструює зростання потенціалу своїх службовців завдяки оптимізації системи соціального захисту, а також трансформації соціально-економічних гарантій. Соціальний захист не обмежується лише системою пільг, він доповнюється системою гарантій, спрямованих на подолання ризиків діяльності, здійснення мотивації якісного виконання службових функцій. Соціально-економічні параметри відображають не лише рівень мінімального матеріального забезпечення військовослужбовців, а й показують відповідність характеру і діапазону виконуваних дій військовослужбовців, а також їх характеру і обсягу.

Оцінка соціально-економічних гарантій визначається через аналіз процесів досягнення результатів гарантування захисту, підвищення ефективності державної соціальної політики. Вона повинна оцінюватися в результаті аналізу системи гарантій рівня державного забезпечення умов життєдіяльності військовослужбовців. Формування необхідного доходу військовослужбовця створює умови дотримання базових соціальних прав і забезпечує мінімальний рівень задоволення потреб, спрямованих на відновлення їх фізичного та інтелектуального потенціалу. При цьому мінімально необхідний рівень задоволення біологічних потреб може оцінюватися через аналіз рівня забезпечення гарантій за переліком мінімальних соціальних стандартів.

Широкий комплекс оцінки соціальноекономічних гарантій повинен включати в себе аналіз практик захисту найважливіших прав особистості на отримання та використання житла, забезпечення повноцінного відпочинку, надання якісних медичних і освітніх послуг. Ці гарантії охорони життя і здоров'я, матеріального забезпечення уособлює основний регулятор суспільних відносин, застосовуваний в межах того чи іншого рівня розвитку соціального захисту військовослужбовців. Соціальноекономічні гарантії фіксуються на законодавчому рівні в системіадміністративнихположень організаційних структур, визначають форми і якісні характеристики соціального захисту військовослужбовців. Отже, формування системи соціального захисту військовослужбовців здійснюється шляхом впровадження суспільно необхідних параметрів соціальних гарантій.

\section{ЛІТЕРАТУРА:}

1. Дзюндзюк В. Зміна ролі держави в умовах глобалізації. Теорія та історія державного управління. Харків, 2011. № 2. С. 23-27.

2. Кроква С. Правове виховання військовослужбовців, його організація та фрорми. Право військової сорери. Київ, 2007. № 7. С. 7-9.

3. Кузнецов Ю. Психологи для учасників АТО. Військо України. Київ, 2014. № 9 (168). С. 30-35.

4. Маковчук Ф. Військова служба правопорядку у Збройних Силах України : сьогодення та перспективи розвитку. Наука і оборона. Київ, 2011. № 1. С. 25-31.

5. Парубчак И. Соотношение культурно-воспитатильной функции с другими сферами и ведомствами государства с целью повышения эфективности социализационных процесов в стране. Социальногуманитарный весник Юга России. 2013. С. 126-135.

6. Резнікова О., Цюкало В., Паливода В., Дрьомов С., Сьомін С. Концептуальні засади розвитку системи забезпечення національної безпеки України : аналіт. доп. Київ : НІСД, 2015. 58 с. 